\title{
The significant of internet technology to education and students in acquiring quality education
}

\author{
Salisu Abdullahi' ${ }^{1}$, Emmanuel N. Ransom ${ }^{2}$, M. S. Kardam ${ }^{1}$ \\ ${ }^{1}$ Department of Surveying \& Geo-Informatics, The Federal Polytechnic, Bauchi, Nigeria \\ ${ }^{2}$ Department of General Studies Education, Federal College of Education, Pankshin, Nigeria
}

\begin{abstract}
The paper look at how internet technologies provide rich and flexible media for representing what students know and what they are learning. It also discusses the various internet technologies that every educator should understand and its expected use in the classroom with their students. It has also explored the benefits of internet technologies as a tool in teaching learning process and also promotes the opportunities of restructuring the teaching process.
\end{abstract}

Keywords: internet technologies; teaching process; education, Nigeria

\section{INTRODUCTION}

One of the basic functions of education is preparation of students for life. This function in $21^{\text {st }}$ century may be participation in an information rich society, where knowledge is regarded as the main source for socio-cultural and politico-economical development of countries and/or nations. Information rich societies are developed and dominating and they are controlling the information throughout the world.

The advent of Internet Technologies has inevitably changed the way we acquired knowledge. These technologies, as well as others, have altered the method in which people learn, work, communicate, and even shop. Today, internet tools such as e-mail, satellite connections, and video conferencing software have provided educators with the tools to provide synchronous as well as asynchronous communication with their students.

The use of internet technologies in education has grown tremendously. Online courses, which may or may not provide teacher-student interaction, are becoming the most common form of acquiring qualitative education.

Educators and Students who have unlimited access to internet technologies at school and/or at home tend to be more knowledgeable and have more computer experience than those that do not (Zeliff, 2004). In an underprivileged environment, be it school or home, the hardware and software needed to increase internet technology use is often nonexistent. If students have limited access to internet, it may have an impact on their learning capabilities. Educators have almost always tried to use technologies to teach students in the same ways that teachers had always taught. So information was recorded in the technology (e.g., the content presented by films and television programs), and the technology presented that information to the students. The students' role was to learn the information presented by the technology, just 
as they learned information presented by the teacher. The role of the technology was to deliver lessons to students, just as trucks deliver groceries to supermarkets (Clark, 1983). If you deliver groceries, people will eat. If you deliver instruction, students will learn.

The introduction of internet technologies in classrooms has followed the same pattern of use. Before the advent of microcomputers in the $1980 \mathrm{~s}$, mainframe computers were used to deliver drill and practice and simple tutorials for teaching students lessons. When microcomputers began populating classrooms, the natural inclination was to use them in the same way.

Later in the 1980s, educators began to perceive the importance of internet technologies as productivity tools. The growing popularity of word processing, databases, spreadsheets, graphics programs, and desktop publishing was enabling learning to become more easily. So students in classroom began word processing and using graphics packages and desktop publishing programs to write assignment.

The development of inexpensive multimedia computers and the eruption of the Internet technologies in the mid-1990s quickly changed the nature we acquire knowledge. Communications tools (e.g., e-mail and computer conferences) and multimedia, little used according to Hadley and Sheingold, have dominated the role of technologies in the classroom ever since. But what are the students producing? Too often, they are using the technology to reproduce what the teacher or textbook told them or what they copy from the Internet.

\section{Internet Technologies used by Educators and Students}

Some of the internet technologies that every educator should understand and is expected to use in the classroom with their students are:

\section{Video and Podcasting}

One of the most widely adopted internet technologies for use in instructional settings is video streaming. Between YouTube, TeacherTube, EduTube, and many other video hosting sites, there are an abundance of lectures, how-to videos, and supporting materials available in the form of web based video. Podcasting has also been used to provide similar offerings of audio materials through popular sites like iTunes.

\section{Presentation Tools}

This category is vast and rich. There are hundreds (perhaps thousands) of tools on the Internet that can be used to create and share presentations, from simple Power point slide players like Slideshare to multimedia timeline tools like Vuvox and OneTrueMedia. These tools can be used to support classroom teaching or distance learning, or for student reports and presentations.

\section{Collaboration \& Brainstorming Tools}

This is another wide ranging category, including thought-organizing tools like mindmap and bubblus, and collaborative tools like web based interactive whiteboards and Google Documents. Additionally, some of the other tools in this list, such as wikis and virtual worlds, also serve as collaboration tools. 


\section{Blogs \& Blogging}

Bloggers and many other regular Internet users are well aware of blogs and blogging, but there are many other professionals who really are not frequenters of the blogosphere. In addition to a basic familiarity with this technology, educators should be aware of sites like Blogger and WordPress, where users can quickly and easily create their own blogs for free.

\section{Wikis}

The use of Wikis in educational settings is growing every day. Sites like Wet paint and others allow users to create free wiki web sites and are a great way to get started with using wikis for educational applications.

\section{Social Networking}

All educators should have a basic understanding of sites like Facebook and MySpace and how they are used. This doesn't mean they need accounts on these sites (and many educators would recommend against using these sites to communicate with their students), but they should understand what they are and how they are being used. Educators should also be aware of the professional social networking site LinkedIn.

\section{IM}

A large percentage of students use IM regularly, via Aim, IM aggregator site Meebo (Meebo allows users to combine messaging from Aim, Yahoo, MySpace, Facebook, and other sites), or other tools. Educators should be aware.

\section{Twitter}

This listing is really focused on technologies, not specific applications, but this application is currently just too popular to ignore. Educators should at least understand what it is and the fundamentals of how it is used.

\section{Virtual Worlds}

This technology has received a lot of press, with SecondLife being the clear leader thus far in this application area. In my experience, the use of SecondLife has been somewhat constrained by high bandwidth and processing power requirements, but this also means that there is still considerable room for increased adoption of the application as systems continue to become more powerful and higher speed bandwidth more prevalent. Active Worlds is one of the number of competitive technologies, and provides a "universe" dedicated to education that has been popular with educators.

\section{RSS Feeds}

RSS allows users to create their own push data streams (that is, define data flows you want coming to you automatically, rather than having to go and "pull" the information with a Google search or other browsing effort). RSS feeds enable you to take advantage of streams of published content that will be sitting in your In Box, or in an RSS reader, when you want them. There are RSS feeds available for many topics and many web sites. 


\section{THE ROLE INTERNET TECHNOLOGIES IN TEACHING LEARNING PROCESS}

\section{Making Students Independent in their Studies}

Using internet technologies students can decide about their own studies, learning time, place and resources in a better way. Students can work in more supportive environments, seek help from teachers and fellows, and share their learning experiences and ideas in romantic and productive fashion.

Dede (1996, p. 4) stated that the development of high performance computing and communication is creating new media such as the www and virtual realities. In turn these new media enable new type of messages and experiences, such as interpersonal interactions in immersive synthetic environments lead to the formation of virtual communities. The innovative kinds of pedagogy empowered by these emerging media and experiences promoted the opportunities of distance education and at present virtual education and eliminated the barriers of distance and time. New and innovative learning experiences would be enhanced and encouraged by these technologies, as by virtual communities, which exist by interactions across the globe through global network of computers round the clock.

The global sharing of experiences would make possible the group presentation form of instruction in distance education. Distance education encompasses and relies on the use of internet technologies to make learning more productive and more individualized, to give instruction a more scientific base and make it appropriate $\&$ more effective, learning more immediate and access to resources more equal. These remarkable aspects can expand the quality and quantity of instructional resources. They can serve learners at their ease in terms of time and place. Rashid (2001, p. 270) stated that:

- Both educators and learners can work with others at remote sites.

- The community of learners can expand to include virtually anyone who wishes to obtain information and who is not excluded by policy or cost.

- They can provide real access to experts in universities, research laboratories, the business community, government agencies and political offices.

\section{The role of Internet technologies in restructuring the teaching learning process}

Internet technologies can transform teaching and learning process by offering alternatives to the educators and students in providing latest information, access to virtually unlimited resources and opportunities for real world communication, collaboration and competition. The phases of this process as described by Marriam et al (1997, p. 34) are:

- Developing awareness - recognizing that something is wrong or different.

- Exploring alternative-researching for new ideas from other institutions and acknowledging that change is needed.

- Making a transition-leaving the old approaches behind (or dramatically changed).

- Achieving integration-putting the pieces from the transition phase back together and

- Taking action-putting new ideas into operation.

The process can work at instructional programme or institutional level and one or more phases work simultaneously. Traditional lectures and demonstrations can become web-based multimedia learning experiences. 
Internet technologies can enrich the learning resources and institutions refocus from teaching to learning, from teacher to learner. It can create learning environment throughout the world by networked learning communities. Networks may create educative environments embedded in democratic philosophy of instruction and helping learners learn. The characteristics of which are:

- Respect for personality;

- Participation in decision-making;

- Freedom of expression and availability of information; and

- Mutuality of responsibility in defining goals, planning and conducting activities and evaluating the process (Knowles 1980, p. 85).

Learning may take place more effectively and dynamically in educative environments where teacher and learners are open to each other to interact and exchange information and experiences in a friendly way. Educative environments can enhance and shape the teaching learning process to achieve the desired goals. There is a natural tendency for students to learn and learning can accelerate, in interactive and encouraging environments. Accelerating the encouraging environments may be psychological climates and student's interactions can create them. Interactions of students can make learning environment more effective and meaningful and much of learning takes place in a meaningful environment. Learners may get immediate feedback and reinforcement through the use of internet technologies.

Desired learning always requires access to qualitative and latest information resources and internet technology confirms the increased access to such resources at students pace. Moreover, there is no denying that internet technology based courses open new educational access to the non-traditional and geographically dispersed students. The on-line setting provides a level of flexibility and convenience not provided by traditional classroom courses. Aggarwal (2000, p. 11)

Internet technologies provide learners latest relevant information at their own pace and they can form a virtual community of learners at global level. Teaching organizations are adopting internet technologies because of their cost effectiveness, access and flexibilities of choices.

\section{Students Use Internet Technologies to:}

- Participate in a media revolution, profoundly affecting the way they think about and use internet technologies.

- Improve the ways of learning in new learning fashions

- Extend the ability and skills of applying their learning in real situation.

- Working in groups for cooperative and collaborative learning.

- Developing self-learning habits at their own pace and time.

- Learn with the teacher rather by the teacher.

- Develop inquiry-learning habits.

- Use right information at right time to achieve right objective.

- Review and explore qualitative data.

- Exchange learning experiences and information with others students and teachers living anywhere in the world. 
Internet technologies facilitate students in their learning process through their active participation on one hand and help teachers on the other hand.

Therefore, educators use the Internet Technologies to:

- Present the material in more interesting and attractive way.

- Guide and help students in searching the qualitative material.

- Make best use of time.

- Educate the students.

- Provide individualized instruction.

- Direct the students toward cooperative as well as collaborative learning activities.

- Prepare learning material for students, rather teaching in conventional situations.

- Diagnose the learning problem of students and help them to overcome.

- Solve the study problems of students.

Internet technologies affect the teaching and learning process in different ways. These helps the teachers in preparing lecture notes for interesting presentation, on the one hand and facilitates the students on the other hand.

Different technologies help the teachers and students according to their respective nature and capabilities of storage and presentation.

Internet technologies provide the opportunities of global interactions. Students can learn from interactions with the information, interface, teachers and co-learners using global networks. They can interact at their own and get rid of their routine work. They may review and explore the qualitative as well as quantitative data through computer networks. They can work on group projects participating in peer learning and knowledge building activities. Under the influence of internet technologies, teaching and learning occurs in a changed situation.

\section{CONCLUSIONS}

Internet technologies are the result of knowledge explosion. These include; Video and Podcasting, Presentation Tools, Collaboration \& Brainstorming Tools, Blogs \& Blogging, Wikis, Social Networking, IM, Twitter, Virtual Worlds, RSS Feeds and other hardware \& software technologies help educators and students to facilitate teaching and learning process. Using Internet Technologies learners are now able to participate in learning communities throughout the world. They are independent and free in choice of their programmes of study and access to the resources.

Internet technologies facilitate teaching learning process in more productive fashion. Similarly, the role of teacher is also different in new settings than in the conventional system. Teacher facilitates and guides the learners in their study playing the role of a coach or mentor. Now teacher is not at the center of the instruction and sole source of information as in conventional classrooms. He/she decides contents/experiences and/or activities, locates the resources and guides learners how to have access and utilize the information for required outcomes. In a nutshell, internet technologies are restructuring teaching learning process to meet the International standards. 


\section{Recommendations}

If schools are to foster meaningful learning, then the way they use internet technologies in schools must change from technology-as-teacher to technology-as-partner in the learning process.

If internet technologies are used to foster meaningful learning, then they will not be used as delivery vehicles only. Rather, internet technologies should be used as engagers and facilitators of thinking. Based on our conception of meaningful learning, we recommend the following roles for internet technologies in supporting meaningful learning in our schools.

a. The Technology to serve as tools to support knowledge construction: for representing learners' ideas, understandings, and beliefs for producing organized, multimedia knowledge bases by learners.

b. The Technology should serve as information vehicle for exploring knowledge to support learning by constructing, accessing needed information for comparing perspectives beliefs and worldviews.

c. The Technology should be regarded as authentic context to support learning by representing and simulating meaningful real-world problems, situations, and contexts for representing beliefs, perspectives, arguments, and stories of others for defining a safe, controllable problem student face.

d. The Technology as social medium to support learning by conversing for collaborating with others for discussing, arguing, and building consensus among members of a community for supporting discourse among knowledge-building communities.

\section{References}

[1] Aggarwal A. (2000). Web-Bsed Learning and Teaching Technologies: Opportunities and Challenges. London; Idea Group Publishing. Branson, R.

[2] Clark R. E. (1994). Media will never influence learning. Educational Technology, Research and Development, 42; 1042-1629.

[3] Dede C. (1996). The Evolution of Distance Education: Emerging Technologies and Distributed Learning. American Journal of Distance Education, 10(2).

[4] Hussain I. (2005). A Study of Emerging Technologies and their Impact on Teaching Learning Process.

[5] Knowles M. S. (1980). The Growth and Development of Adult Education. In John M. Peter \& Associates (eds.); Building an Effective Adult Education Enterprise, London; Jossey Bass Publishers.

[6] Marriam S. B., Cafarella R. S. (1997). Learning in Adulthood: A Comprehensive Guide, San Francisco, Jossey-Bass Publishers.

[7] Rashid M. (2001). Trends and Issues in Distance Education (Course Code 3703), Islamabad: Allama Iqbal Open University.

[8] Zeliff N. (2004). Pedagogical and technological challenges of the Internet. In D. Christopher \& S. Jaderstrom (Eds.). NBEA 2004 Yearbook, 42; 67-88. 
[9] Dennis Agama Eka, International Letters of Social and Humanistic Sciences 8(2) (2014) 170-182.

[11] Nayereh Shahmohammadi, International Letters of Social and Humanistic Sciences 8(2) (2014) 183-191.

[12] Godwin E. Itua, International Letters of Social and Humanistic Sciences 8(3) (2014) 200-207.

[13] Rowland U. Aleshi, Clementina N. Iloh, International Letters of Social and Humanistic Sciences 8(3) (2014) 208-216.

[14] Hannatu Abdullahi, International Letters of Social and Humanistic Sciences 8(3) (2014) 217-223.

[15] Fowoyo Joseph Taiwo, International Letters of Social and Humanistic Sciences 8(3) (2014) 244-251.

[16] Abdulrahaman W. Lawal, International Letters of Social and Humanistic Sciences 3 (2014) 53-59.

[17] Alaba E. Dare, International Letters of Social and Humanistic Sciences 3 (2014) 73-79.

[18] Grema Maina Bukar, Yohanna A. Timothy, International Letters of Social and Humanistic Sciences 4 (2014) 9-21.

[19] M. N. Modebelu, F. K. Igwebuike, International Letters of Social and Humanistic Sciences 4 (2014) 40-48.

[20] Akor Isaiah Akem, Victor Tavershima Ukeli, International Letters of Social and Humanistic Sciences 4 (2014) 49-59.

[21] Sule Maina, International Letters of Social and Humanistic Sciences 4 (2014) 87-96.

[22] Nwachukwu Uche Emma, International Letters of Social and Humanistic Sciences 5 (2014) 1-12.

[23] Peace Ebele Ilechukwu Chukwbikem, International Letters of Social and Humanistic Sciences 8(1) (2014) 1-17.

[24] Odo John Ogar, International Letters of Social and Humanistic Sciences 8(1) (2014) 28-33.

[25] Halima Sidi Bamall, International Letters of Social and Humanistic Sciences 8(1) (2014) 50-55.

[26] Elizabeth Morenikeji Titilayo Adediran, Albert Oluyomi Kehinde, International Letters of Social and Humanistic Sciences 8(1) (2014) 66-75.

[27] S. A. Kazeem, K. Y. Balogun, International Letters of Social and Humanistic Sciences 8(2) (2014) 108-119.

[28] Nneka Rita Udoye, Victor Etim Ndum, International Letters of Social and Humanistic Sciences 8(2) (2014) 130-139.

[29] Sanusi L. Sa'adatu, International Letters of Social and Humanistic Sciences 8(2) (2014) 140-147.

[30] Benedicta Ehi Momodu, International Letters of Social and Humanistic Sciences 13 (2014) 64-70. 
[31] Adebowale Adeyemi-Suenu, International Letters of Social and Humanistic Sciences 13 (2014) 89-94.

[32] Adebowale Adeyemi-Suenu, International Letters of Social and Humanistic Sciences 14 (2014) 1-6. 